\title{
蛋白質立体構造から安定化のメカニズムを 定量的に理解する方法
}

\author{
協利発酵工業(怢)炈薬研究センター 創楽科学研究所 舩橋 順 \\ 理化学研究所 播磨研究所 油谷克英
}

\begin{abstract}
Jun FUNAHASHI and Katsuhide YUTANI: How to Understand the Mechanism of Protein Stability from the Crystal Structure of a Protein
\end{abstract}

Mutant proteins are useful for study on the mechanism of protein stability. However, it is difficult to evaluate the changes in stability due to mutation, because contributions of amino acid residues to the conformational stability differ depending on their locations even if the same residues are substituted. In order to evaluate each contribution of several factors responsible for protein stability, we determined the crystal structures and measured the protein stability for more than a hundred of mutant human lysozymes. Analyzing this structure/stability database, the parameters of each stabilization factor, such as hydrophobic effect and hydrogen bond, could be estimated. These parameters are available for understanding the thermostabilization mechanism of the proteins from hyperthermophiles and for the computer-aided drug design.

\section{1.はじめに}

蛋白質は，それぞれ生命を維持するために必要な固有の 機能を有して抢り, そ扎らの機能は蛋门缺の立体構造に起 因している. その立体構造に関する情報はアミノ酸配列上 に含まれているが，その解読はいまだに進んでいない，全 ヒトゲノムが解読された今H, 膨大なアミノ酸配列データ をいかにして生体機能の理解につなげ, 医学利用などに発 展させていくかが現代のポストゲノム科学の課題であり， 盛んに研究が行われている.しかしその・jで, 機能発現 に必要な立体構造を構築している個々のアミノ酸残基が, その立体構造の㚣定性にどのような寄与をしているかは， いまだにけ分に説明できていないのが現状である.

蛋白質の安定化メカニズムを，体構造と関連させて定 量的に理解することができれば,機能を損なわずに蛋向質 を安定化させるデザインが可能となり, 種々の過酷な環境 下で期待する機能を有する蛋白質の創生も夢ではなく, 医 学や産業への貢献は計りしれない. 例えばDNA 複製技術 の PCR (Polymerase Chain Reaction) 法で使われるDNA ポ リメラーゼも，高温化で機能を有する蛋白質（好熱菌由来 蛋白質)であり，このように耐熱性・荄定性に優れた蛋白 質はすでに多くの分野で貢献している.

蛋白質を安定化する因子としては, 蛋系質内部の柾水性 相互作用の増強，水素結合・塩結合・SS 結合の形成，二 次構造 ( $\alpha$-helix, $\beta$-strand な゙) の強化，金属イオンの導人 など，さまざまな因子が提案され，個々には実験的に証明

H本結晶学会誌第 47 卷第 4 足
されている. 分子生物兴:の進展によりアミノ酸㯰換蛋白質 の研究が盛んになり相当量のデータが蓄積されているが, アミノ酸㯰換によってそ扎らの安走化因子を蛋白質に導 人したとしても，必ずしも期街どおりの交定化を小さない 場合が多い. 表 1 に数種の蛋白質における疎水性残基変異 型の安定性变化を，例として小す、1 表中のアミノ酸置換 は, 安定化因子の1つである疎水性相互作用を減少させる ため, 安定性の低下が期待される。ここでは置換部位周辺 の環境の違いを補.1E。るため, 野生型構造における残基の 埋礼度で補正してあるが, 例えば Val $\rightarrow$ Ala 置換では安定 性が变化しないものから，20 kJ/mol も不安走化するもの など度合いはさまざまであり，置換により疎水性相互作用 以外の安定化因子にも影響が及んでいることを示唆して いる.このように，间じアミノ酸罱換を導入した場合でさ

表 14 種の蛋白質 (1に扔ける踈水性变異型の安定性变化.1) (Changes in stability of the hydrophobic mutants of four different proteins.)

\begin{tabular}{|c|c|c|c|c|c|}
\hline \multirow[b]{2}{*}{ 変異 } & \multirow[b]{2}{*}{ 阔査数 } & \multicolumn{3}{|c|}{$\Delta \Delta \mathrm{G}^{\mathrm{b}}(\mathrm{kJ} / \mathrm{mol})$} & \multirow{2}{*}{$\begin{array}{c}\Delta \Delta \mathrm{G} /-\mathrm{CH}_{2-} \\
(\mathrm{kJ} / \mathrm{mol})\end{array}$} \\
\hline & & 最小 & 最大 & 平均 & \\
\hline Ile $\rightarrow$ Val & 9 & -2.1 & -9.3 & -5.4 & -5.4 \\
\hline $\mathrm{Val} \cdot \mathrm{Ala}$ & 11 & 0.0 & -19.7 & -10.5 & -5.3 \\
\hline $\mathrm{Ile} \rightarrow \mathrm{Ala}$ & 9 & -4.6 & -21.3 & -15.9 & -5.3 \\
\hline Leu $\rightarrow$ Ala & 17 & -7.1 & -25.9 & -14.6 & -4.9 \\
\hline \multicolumn{6}{|c|}{$\begin{array}{l}\text { a) スタフィロコッカルヌクレアーゼ, T4リゾチーム,バルナーゼ, } \\
\text { ジーン5プロテイン } \\
\text { b) それぞれの㯰換残基が100\%分子内部に埋め迟まれていると換 } \\
\text { 算した值 }\end{array}$} \\
\hline
\end{tabular}


え，期待どおりの安定性变化を得るのは難しい，蛋白質の 安定性は，安定化する因子と，不多起化する因子が複雑に 絡み合い，その微妙なバランス(ほんのわずかなエネルギ 一差)の上に成り立っていて，結果的に変性のギブスエネ ルギー変化はたかだか $40 \mathrm{~kJ} / \mathrm{mol}$ 程度になる (Marginal Stability）.2) そのため,一残基置換といったほんの少しの 変化であっても,その変性のギブスエネルギー変化の何制 かに相当し，見かけのうえでは著しい安定性変化となる。

このような微妙なバランスで蛋白質の多定性は保た机 ているため, 安定化メカニズムを解明するには, 複雑な要 因を解析できるだけのデー夕量が必要となる，そこでわれ われは，実験的扱いが容易なヒトリゾチームを用い，系統 的・網羅的にアミノ酸置換变異型を作製し, そのアミノ酸 置換が立体構造と安定性に及ぼす影響を詳細に調べてい る.ここでは，置換による立体構造変化を，安定性変化と 比較することにより，蛋问質父定化のメカニズムを定量的 に解明しようとする試みについて詳述する。ささらに，そ机 らを用いて好熱菌由来蛋门質の安定化メカニズムを立体 構造より解明する試み、またドラッグデザインや蛋白質製 剂など, 創薬化学に適用できる可能性の例を紹介寸る.

\section{2. ヒトリゾチーム疎水性変異型を用いた研究}

ヒトリゾチーム (HL：図1)は130 残基・分子量 14500 の蛋向質で, X 線結晶構造解析や精度の高い物理化学的研 究が進んでいる，わ扎わ机はまず，安定化肉子の1つであ る疎水性相互作用が安定化に及ぼす影響を明らかにする ため，HLの分子内部や分子表泊などさまざまな環境下に おいて Ile $\rightarrow \mathrm{Val}$ (5 力所) 3) と, $\mathrm{Val} \rightarrow \mathrm{Ala}$ (7 カ所) +1 変異 型を作製し，そ扎らの安定性を熱測定 (示差走査熱量計) で, 構造変化をX線結晶構造解析によって調べた，その結 果，同じアミノ酸置換でも表 1 と同様，努定性変化に差が あったそそこで，その差の原因を明らかにするために，置 換による二次構造傾向性（二次構造中でのアミノ酸残基の 存在頻度)の変化を考慮した.すると, $\Delta \Delta \mathrm{ASA}_{\mathrm{HP}}$ と安定性 変化 $(\Delta \Delta \mathrm{G})$ との間に相関があることがわかった（図2）.5! ここで $\Delta \Delta \mathrm{ASA}_{\mathrm{HP}}$ とは，変性による疎水性アミノ酸側鎖の 溶媒露出表面積 (Accessible Surface Area：ASA) 変化の, 変異型と野生型の差を示す。このことは, 变性により溶媒 に露出する疎水性表面積 (蛋白質内部に埋め込まれている 疎水性残基の面積) の減少に従って安定性が低下寸ること を意味する。この良い相関は，置換残基のみ，または置換 残基周辺の $\Delta \Delta \mathrm{ASA}_{\mathrm{HP}}$ では得ら机ず, 分子全体の $\Delta \Delta \mathrm{ASA}_{\mathrm{HP}}$ を用いることで初めて得ることができた。つまり，置換に よる影響は置換部位周辺だけでなく, 分子全体に及んでい ることを示している. 図2に示すように，置換により゙次 構造の傾向性が高くなる変異型, 例えば $\alpha$-helix 上での Val $\rightarrow$ Ala 変異型の $\Delta \Delta \mathrm{G}$ は，その $\Delta \Delta \mathrm{ASA}_{\mathrm{HP}}$ から期待されるよ りも一様に高くなり, 逆に一次構造の傾向性が低くなる变

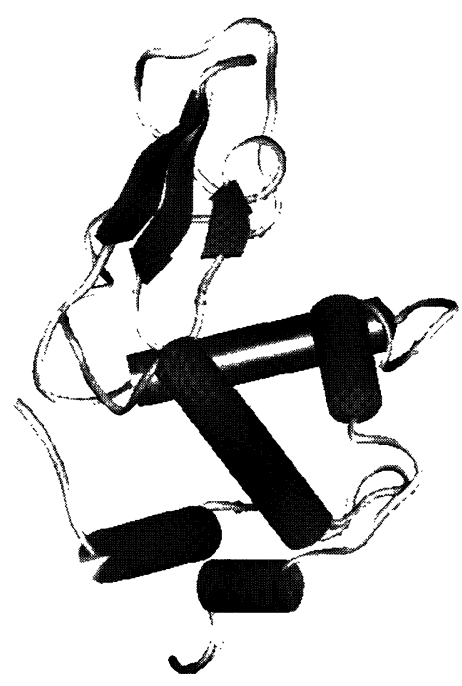

図 1 野生型ヒトリゾチームの立体構造. (Structure of the wild-type human lysozyme.)

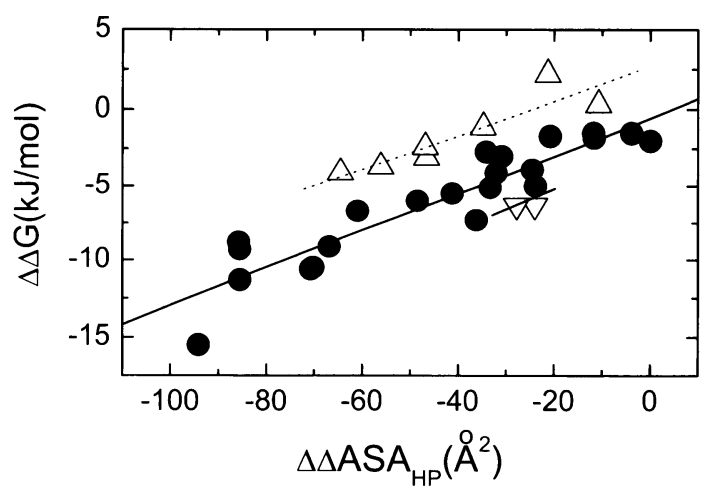

図2 $\mathrm{HL}$ 変異型の安定性変化と疎水性溶媒露出表面積 変化の関係.5) (Correlation of $\Delta \Delta \mathrm{ASA}_{\mathrm{HP}}$ with $\Delta \Delta \mathrm{G}$ for

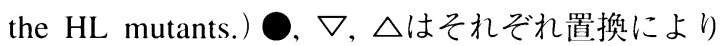
:次構造傾向性が变わらない変異型, 低くなる变 異型，宲くなる変異型を示す。

異型, 例えば $\beta$-strand 上での $\mathrm{Val} \rightarrow \mathrm{Ala}$ 変異型の $\Delta \Delta \mathrm{G}$ は期 待値よりも低くなっている.このことは, 複数の安定化因 子(この場合は疎水性相互作用と二次構造傾向性)の影響 を加算的に近似できる可能性を示している。

\section{3. ヒトリゾチームの系統的・網羅的変異型を用い た研究}

このように系統的な変異型の安定性変化と構造変化を 関連付けることで, 個々の安定化因子の役割を示せる可能 性があることがわかった：そこでわれわれは，さまざまな 安定化因子の寄与を明らかにするために, 表 2 に示すよう な HLの系統的・網羅的変異型を作製してきた．置換部位 は分子内部や分子表面, $\alpha$-helix 上や $\beta$-strand 上, loop 上な どさまざまな環境トにあり，置換する残基も多様である。 これらの変異型の X 線結晶構造解析を行った結果, 小さ い残基に置換することによって分子内部に水分子が新た 
表2 取り扱ったHL 変異型の種類. (The list of HL mutants examined in our studies.)

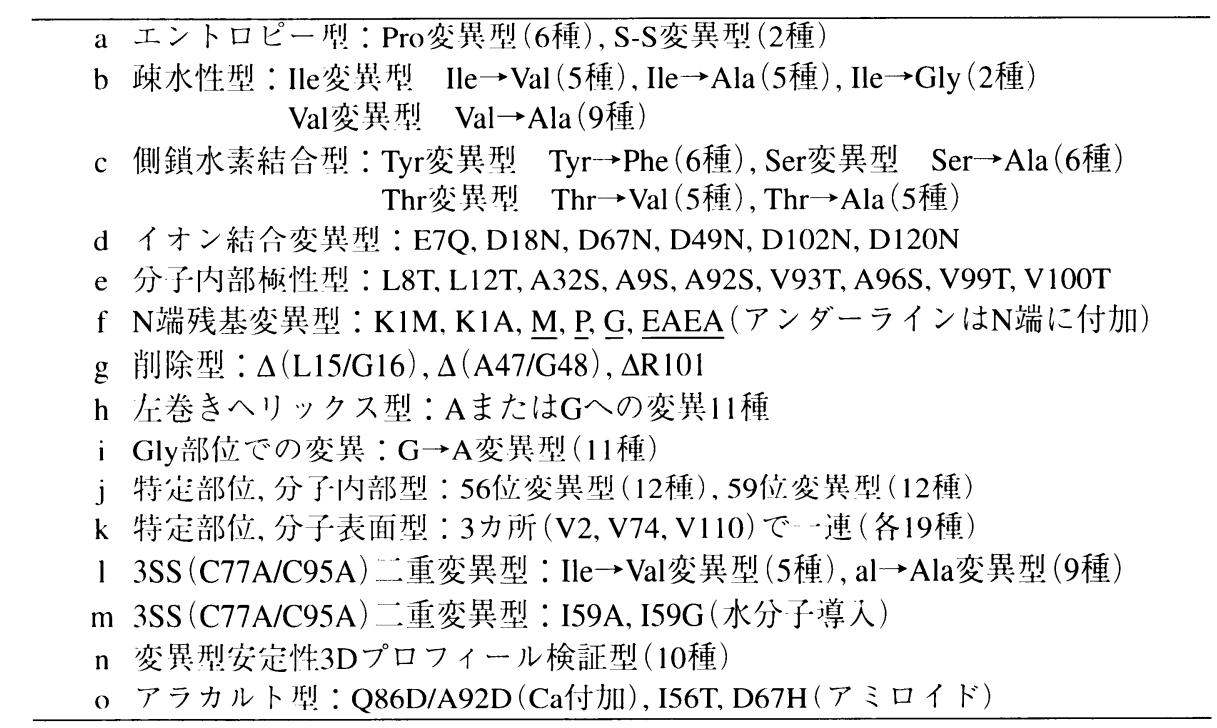

に取り込まれるなど，一残基置換がさまざまな構造変化 を起こすこともわかった.4)この系統的・網羅的変異型ヒ トリゾチームの立体構造／安定性のデー夕を用い,すべ ての変異型の安定性変化を統一的に説明する,つまり安 定化因子の寄与を定量的に見積もる新たな試みを行って (る.6)

われわれが注目した安定化因子は, 疎水性相互作用, 水 素結合, 分子内水分子; 分子内キャビティ, 側鎖のエント ロピー, 二次構造傾向性である。これらの安定性への寄与 を，それぞれ $\Delta \Delta \mathrm{G}_{\mathrm{HP}}, \Delta \Delta \mathrm{G}_{\mathrm{HB}}, \Delta \Delta \mathrm{G}_{\mathrm{H} 2 \mathrm{O}}, \Delta \Delta \mathrm{G}_{\mathrm{cav}}, \Delta \Delta \mathrm{G}_{\mathrm{conf}}$, $\Delta \Delta \mathrm{G}_{\mathrm{sp}}$ とする，变異型の安定性変化 $(\Delta \Delta \mathrm{G})$ がこれらの和 であると仮定すると, 次式が成立する。

$$
\begin{aligned}
\Delta \Delta \mathrm{G} & =\Delta \Delta \mathrm{G}_{\mathrm{HP}}+\Delta \Delta \mathrm{G}_{\mathrm{HB}}+\Delta \Delta \mathrm{G}_{\mathrm{H} 2 \mathrm{O}} \\
& +\Delta \Delta \mathrm{G}_{\mathrm{sp}}+\Delta \Delta \mathrm{G}_{\mathrm{cav}}+\Delta \Delta \mathrm{G}_{\mathrm{conf}}+\Sigma \Delta \Delta \mathrm{G}_{\mathrm{i}}
\end{aligned}
$$

ここで $\Delta \Delta \mathrm{G}_{\mathrm{i}}$ は上に述べた以外の安定化因子の寄与を示 し，イオン結合など今後定量化していく予定のものを示 すが, 現状では目的以外の因子に影響しないと判断でき る変異型に限定して解析している. 例えば, 表2 中のイオ ン結合変異型は, イオン結合の影響を考慮する必要があ るため,ここでの解析には用いていない. それぞれの安定 化因子の寄与を, 次のように構造変化と関連づける.

$$
\begin{aligned}
\Delta \Delta \mathrm{G}_{\mathrm{HP}}= & \alpha \Delta \Delta \mathrm{ASA}_{\text {non-polar }}+\beta \Delta \Delta \mathrm{ASA}_{\text {polar }} \\
\Delta \Delta \mathrm{G}_{\mathrm{HB}}= & \gamma_{[\mathrm{pp}]} \sum \mathrm{r}_{\mathrm{HB}[\mathrm{pp}]}{ }^{-1}+\gamma_{[\mathrm{pw}]} \Sigma \mathrm{r}_{\mathrm{HB}[\mathrm{pw}]}{ }^{-1} \\
& +\gamma_{[\mathrm{ww}]} \sum \mathrm{r}_{\mathrm{HB}[\mathrm{ww}]}^{-1} \\
\Delta \Delta \mathrm{G}_{\mathrm{H} 2 \mathrm{O}}=\delta \mathrm{n}_{\mathrm{H} 2 \mathrm{O}} & \\
\Delta \Delta \mathrm{G}_{\mathrm{sp}}= & \varepsilon_{[\alpha]} \Delta \operatorname{pro}_{[\alpha]}+\varepsilon_{[\beta]} \Delta \operatorname{pro}_{[\beta]}
\end{aligned}
$$

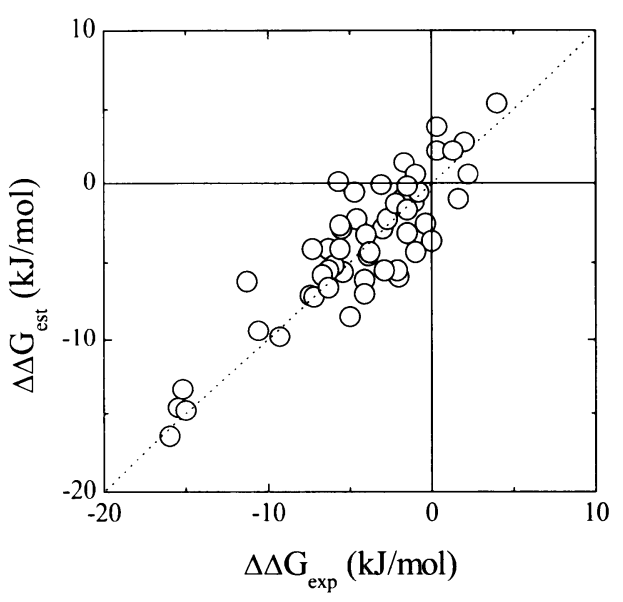

図3式 (1) を用いて 54 種の HL 変異型をフィッティン グした結果.6)(The results of the fitting according to Equation 1 for $54 \mathrm{HL}$ mutants.) 点線は $\mathrm{y}=\mathrm{x}$ を 示す.

$$
\Delta \Delta \mathrm{G}_{\mathrm{cav}}=\zeta \Delta \mathrm{V}_{\mathrm{cav}}
$$

ここで $\mathrm{ASA}_{\text {non-polar }}$ と $\mathrm{ASA}_{\text {polar }}$ はそれぞれ $\mathrm{C} / \mathrm{S}$ 原子, N/O 原 子の ASA を, $\mathrm{r}_{\mathrm{HB}[\mathrm{pp}]}, \mathrm{r}_{\mathrm{HB}[\mathrm{pw}]}$ と $\mathrm{r}_{\mathrm{HB}[\mathrm{ww}]}$ はそれぞれ蛋白質一 蛋白質間, 蛋白質一水分子間, 水分子一水分子間の水素結 合距離, $\mathrm{n}_{\mathrm{H} 2 \mathrm{O}}$ は分子内水分子の数, $\operatorname{pro}_{[\alpha]}$ と $\operatorname{pro}[\beta]$ はアミ ノ酸残基の一次構造傾向性, $\mathrm{V}_{\mathrm{cav}}$ はキャビティ体積を示し,

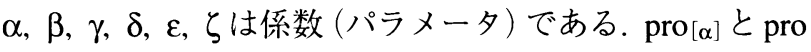
|及] の值と $\Delta \Delta \mathrm{G}_{\mathrm{conf}}$ は文献值を用いた. 54 種の $\mathrm{HL}$ 変異型の デー夕を基に, 式 (1) から算出される安定性 $\left(\Delta \Delta \mathrm{G}_{\mathrm{est}}\right)$ と, カロリメトリーから得られる実験值 $\left(\Delta \Delta \mathrm{G}_{\mathrm{exp}}\right)$ が最も適合 する $\alpha, \beta, \gamma, \delta, \varepsilon, \zeta の$ 值を最小自乗法で求めた. その結 果, 相関係数 (R) が 0.89 , 標準偏差 $(\mathrm{SD})$ が $2.2 \mathrm{~kJ} / \mathrm{mol}$ で それぞれの係数を決定することができた. 図3と表 3 にそ の結果示す。これらのパラメータの值は, 分子内部に埋れ 
表 $3 \mathrm{HL}$ 変異型と T4L 変異型，および両変異型を用いて 決定した安定化因子のパラメータ.0) (The parameters of each stabilization factor determined using HL, $\mathrm{T} 4 \mathrm{~L}$, and both of them.)

\begin{tabular}{|c|c|c|c|c|}
\hline & & HL & $\mathrm{T} 4 \mathrm{~L}$ & $\mathrm{HL}+\mathrm{T} 4 \mathrm{~L}$ \\
\hline \multirow[t]{2}{*}{$\Delta \Delta \mathrm{G}_{\mathrm{HP}}$} & $\alpha$ & 0.154 & 0.122 & 0.146 \\
\hline & $\beta$ & -0.026 & 0.049 & 0.021 \\
\hline \multirow{3}{*}{$\Delta \Delta \mathrm{G}_{\mathrm{HB}}$} & $\gamma_{[\pi \pi]}$ & 25.70 & 16.44 & 22.08 \\
\hline & $\gamma_{[\pi \omega \mid}$ & 14.13 & 16.36 & 9.13 \\
\hline & $\gamma_{[\omega \omega]}$ & 17.13 & - & 7.70 \\
\hline$\Delta \Delta \mathrm{G}_{\mathrm{H} 2 \mathrm{O}}$ & $\delta$ & -8.45 & - & -4.51 \\
\hline \multirow{2}{*}{$\Delta \Delta \mathrm{G}_{\mathrm{pro}}$} & $\varepsilon_{|\alpha|}$ & 5.09 & 0.79 & 3.33 \\
\hline & $\varepsilon_{[\beta]}$ & 2.05 & - & 0.11 \\
\hline$\Delta \Delta \mathrm{G}_{\mathrm{cav}}$ & $\xi$ & -0.052 & -0.088 & -0.073 \\
\hline \multicolumn{2}{|c|}{$\mathbf{R}$} & 0.89 & 0.89 & 0.86 \\
\hline
\end{tabular}

ている疎水性表面積, 親水性表面積が $1 \AA^{2}$ 増加するとそ れぞれ $0.154 \mathrm{~J} / \mathrm{mol}$ の安定化, $0.026 \mathrm{~kJ} / \mathrm{mol}$ の不安定化に影 響し, $3 \AA$ の水素結合形成は, 蛋白質一蛋白質間, 蛋白質一 水分子間，水分子一水分子間でそれぞれ 8.6, 4.7, 5.7 $\mathrm{kJ} / \mathrm{mol}$ の安定化, 水 1 分子が蛋白質内部に導入されるエン トロピー的影響は $8.45 \mathrm{~kJ} / \mathrm{mol}$ の不安定化, キャビティが $1 \AA^{3}$ 増えると $0.052 \mathrm{~kJ} / \mathrm{mol}$ の不安定化に影響することを 示している.また二次構造傾问性の影響は, 例えば, Alaは $\alpha$-helix 形成能, Val は $\beta$-strand 形成能が吕いことが知られ ているが, $\alpha$-helix 上での Val $\rightarrow$ Ala 置換は $3.0 \mathrm{~kJ} / \mathrm{mol}$ の 安定化, $\beta$-strand 上での同置換は $1.5 \mathrm{~kJ} / \mathrm{mol}$ の不安定化で あることを示している，興味深いことに，これらパラメー 夕の符号は，すべて同時に決定したにもかかわらず，論理 的に予測される符号 (例えば水素結合は安定化に寄与する から十など)とすべて一致していた。

\section{4. その他の安定化因子について}

このように, 変異型蛋白質の立体構造／安定性のデー 夕を用いて, さまざまな安定化因子の寄与を定量的に見 積もることができる可能性が示唆された．さらに多くの データを用いることによって，蛋白質の安走性に寄与す るほかの因子についても, 同様に定量化できると考えら れる. 次にイオン結合7) と水和構造8)を例として挙げる.

イオン結合は, 疎水性相互作用などと同様に安定化に 重要だと考えられている。高い熱安定性をもつ好熱菌由 来蛋白質は, 常温菌由来蛋白質に比べ, 統計的に分子表面 のイオン結合が多いことから，それらが蛋白質の安定性 に寄与していると注目されている。そこでHLの分子表 面でイオン結合を形成している残基を置換した6変異型 （表2）を作製して熱測定を行い, 3 变異型については構造 解析を行った. 結果, イオン結合を 1 本除去した変異型は $2.8 \sim 9.4 \mathrm{~kJ} / \mathrm{mol}(\mathrm{pH} 4.0)$ と, さまざまに不安定化してい た. 構造解析した 3 変異型について, 先に決定されたパラ メータを用いてイオン結合以外の安定化因子の寄与を算
表4 分子内部と分子表面の水素結合と水分子の奇与. (Contributions of hydrogen bonding and water molecules inside and outside of a protein.)

\begin{tabular}{|c|c|c|c|}
\hline & パラメータ & 分与内部 & 分子表面 ${ }^{\dagger}$ \\
\hline \multirow[t]{3}{*}{$\Delta \Delta \mathrm{G}_{\mathrm{HB}}$ or $\Delta \Delta \mathrm{G}_{\mathrm{HB}^{+}}^{\dagger}$} & $\gamma_{[p p]}$ or $\gamma_{[p p]^{+}}$ & 25.70 & 4.47 \\
\hline & $\gamma_{|p w|}$ or $\gamma_{|p w|}{ }^{\dagger}$ & 14.13 & 4.14 \\
\hline & $\gamma_{[w w]}$ or $\gamma_{|w w|^{\dagger}}$ & 17.13 & 1.19 \\
\hline$\Delta \Delta \mathrm{G}_{\mathrm{H} 2 \mathrm{O}}$ or $\Delta \Delta \mathrm{G}_{\mathrm{H} 20}{ }^{*}$ & $\delta$ or $\delta^{\dagger}$ & -8.45 & -1.21 \\
\hline
\end{tabular}

出した結果, プロトネーションのためイオン結合の安定性 への寄与が消失すると考えられる $\mathrm{pH} 2.0$ での熱測定の実 測值とほぼ一致していた。そこで，イオン結合の寄与 $\left(\Delta \Delta \mathrm{G}_{\mathrm{ELE}}\right)$ を $\mathrm{pH} 2.0$ と $\mathrm{pH} 4.0$ の $\Delta \Delta \mathrm{G}$ の差として算出すると $3.2 \sim 8.4 \mathrm{~kJ} / \mathrm{mol}$ となり, これらはイオン結合を形成して いる N/O 原子・の埋れ度と相関し, 完全に埋れている場合は 約 $9 \mathrm{~kJ} / \mathrm{mol}$ の安定化に寄与するということがわかった.7)

水和構造は, 蛋白質の分子表面に rigidに形成している ことがX 線結晶構造解析により報告されており,9”蛋白質 の安定性に影響を及ぼしていると考えられる。そこで, HL の分子表面のVal (3カ所) を一連のアミノ酸に置換した 19変異型 (表2) を作製し, 熱測定と構造解析を行った. 構 造解析の結果, 置換部位周辺で観測された水素結合や結合 水分子の数が変化していることがわかった. 水和構造の変 化の寄与 $\left(\Delta \Delta \mathrm{G}_{\mathrm{HS}}\right)$ は分子表面の水素結合や結合水分子の 数の変化と関連すると考えられるが, 式 (3) や式 (4) で表 される分子内部での影響とは大きさが違うと考えられる. そこで, $\Delta \Delta \mathrm{G}_{\mathrm{HS}}$ を以下の式で表した。

$$
\begin{aligned}
\Delta \Delta \mathrm{G}_{\mathrm{HS}}= & \Delta \Delta \mathrm{G}_{\mathrm{HB}}^{\dagger}+\Delta \Delta \mathrm{G}_{\mathrm{H} 2 \mathrm{O}^{\dagger}}^{\dagger} \\
= & \gamma_{[\mathrm{pp}]}^{\dagger} \Sigma \mathrm{r}_{\mathrm{HB}[\mathrm{pp}]}^{\dagger-1}+\gamma_{[\mathrm{pw}]}^{\dagger} \Sigma \mathrm{r}_{\mathrm{HB}[\mathrm{pw}]}^{\dagger-1} \\
& +\gamma_{[\mathrm{ww}]}^{\dagger} \Sigma \mathrm{r}_{\mathrm{HB}[\mathrm{ww}]}^{\dagger-1}+\delta^{\dagger} \mathrm{n}_{\mathrm{H} 2 \mathrm{O}^{\dagger}}
\end{aligned}
$$

ここで†印は分子表面のものであることを示す.イオン結 合のケースと同様, 先に決定されたパラメータを用いて算 出したほかの因子の寄与を, $\Delta \Delta \mathrm{G}_{\exp }$ から差し引いた值を $\Delta \Delta \mathrm{G}_{\mathrm{HS}}$ とし, 式 (7) を用いてパラメータを算出した. 表 4 に示すように, 分子内部の変化に比べれば影響は少ない が, 分子表面の水和構造も蛋白質の安定性に影響し, それ らを定量化することができた 8

例に示したとおり，立体構造／安定性のデータから得ら れたパラメータを用いることによって,これまで考慮した 安定化因子以外の因子の寄与についても, 同様に定量化で きると考えられる. 今後, それらの因子に影響を与える系 統的変異型の実験結果を基にした定量化が期待される.

\section{5. ヒトリゾチームで決定されたパラメータはほか の蛋白質にも適用できるか ?}

HL で定量化することができた安定化因子の寄与が，ほ 日本結晶学会誌 第 47 巻 第 4 号 (2005) 
(a)

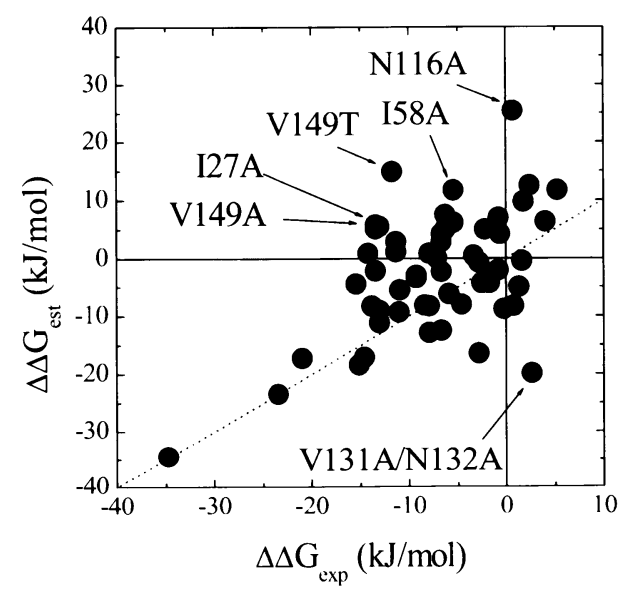

(b)

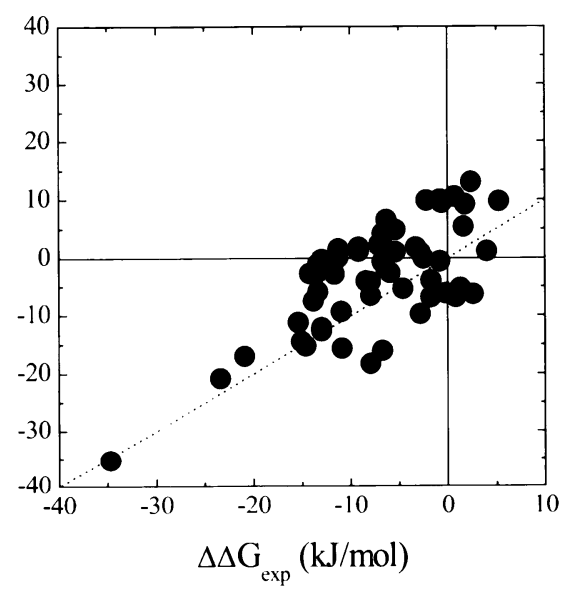

図4 HLのパラメータを用いて算出した T4L 変異型 (54 種)の安定性と実測值の相関.6) (The relation between experimental and estimated $\Delta \Delta \mathrm{G}$ of 54 mutant T4L using the parameters derived from HL mutants.) (a) PDB 登録構造の ASA を用いたプロット.(b) B-factorが高い原子を除いたASAを用いたプロット.

(a)

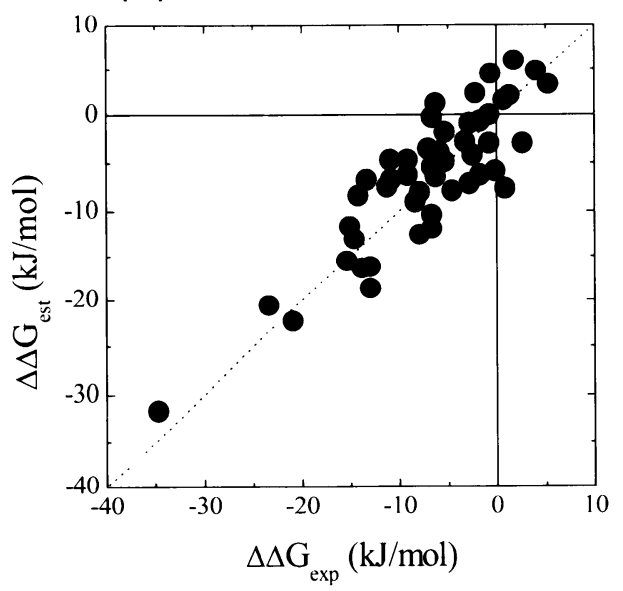

(b)

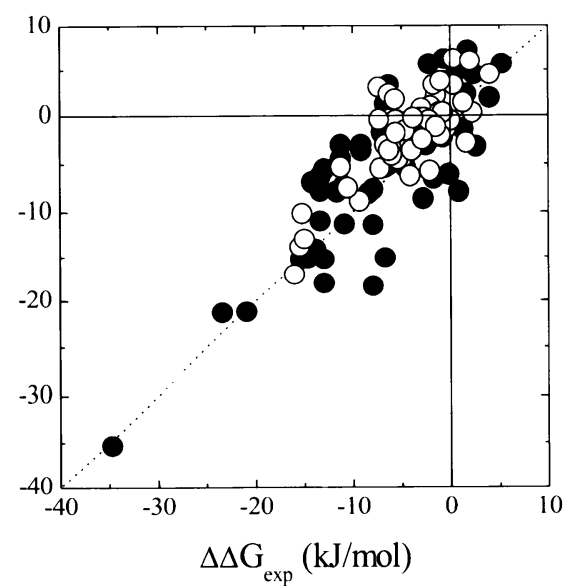

図5 式(1) を用いてフィッティングした結果.6) (The results of the fitting according to Equation 1.) 点線はy=xを示 す.（a）T4L 変異型を用いた結果．（b）HL 変異型（○）と T4L 変異型 $(O)$ の両者を用いた結果.

かの蛋白質にも同様に適用できるかどうかを確認するた め, 変異型の立体構造/安定性のデータが豊富な $\mathrm{T} 4$ リゾ チーム（T4L）を用いて検証した。）文献で安定性が報告さ れている変異型の中から, HLの場合と同様の観点で 54 種 の変異型を選択し，立体構造はPDBより, 安定性デー夕 は文献より抽出した。

式 (1) で算出される $\mathrm{T} 4 \mathrm{~L}$ 変異型の $\Delta \Delta \mathrm{G}_{\mathrm{est}}$ と実測值との 相関を図 $4 \mathrm{a}$ に示すが, $\Delta \Delta \mathrm{G}_{\mathrm{est}}$ と $\Delta \Delta \mathrm{G}_{\mathrm{exp}}$ の差が非常に大 きい $(\mathrm{SD}=10.0 \mathrm{~kJ} / \mathrm{mol})$ ．そこで, 差が大きい変異型につ いてその差に起因する因子を調べたところ, 分子表面に 位置するLys や Arg 残基の配座が野生型と異なり, $\triangle \triangle \mathrm{ASA}_{\text {polar }}$ の值が極端に大きくなっていたためであった. PDB 登録構造におけるこれらの残基の温度因子 (B-factor) はいずれも約 $100 \AA^{2}$ と非常に高く, その構造不確定性に 日本結晶学会誌 第 47 巻 第 4 步 (2005)
よりずれが生じていることがわかった。一方，われわれが 解析に用いた HL 変異型の B-factor はすべて $60 \AA^{2}$ 以下で ある、そこで, T4L変型型の構造から, B-factorが $70 \AA^{2}$ 以上の原子を除外したASAを用いて再計算した相関を 図 $4 b$ に示す。この場命, $\Delta \Delta \mathrm{G}_{\mathrm{est}}$ と $\Delta \Delta \mathrm{G}_{\mathrm{exp}}$ の差は少なくな っていた $(\mathrm{SD}=7.6 \mathrm{~kJ} / \mathrm{mol}) . \Delta \Delta \mathrm{G}_{\mathrm{est}}$ は $\Delta \Delta \mathrm{ASA}$ の值に大き く影響を受けるため, B-factorの低い, 精度の高い構造デ ータを使用することが必姴である。

このように，HLから得られたパラメータを用いること により，T4Lの立体構造から安定性を粗く見積もることが できた，そこで次に，B-factorが高い原子が多かった変異 型を除いた T4L 変異型 (48種)のデータのみを用いてパ ラメータを決定，またはHLと T4Lの軕方の変異型データ (110種)を用いてパラメー夕を決定することを試みた。 そ 
の結果, T4 リゾチームだけの場合は $\mathrm{R}=0.89(\mathrm{SD}=3.9$ $\mathrm{kJ} / \mathrm{mol}$ ) (図 $5 \mathrm{a})$, 両者の場合は $\mathrm{R}=0.86(\mathrm{SD}=4.3 \mathrm{~kJ} / \mathrm{mol})$ (図5b)でそれぞれのパラメー夕を決定した。決定された パラメータを表3に示す。ただし，T4L変異型は， $\beta$-strand 上での变異型や, 置換により水分子一水分子間の水素結合 や分子内水分子に変化が生じた变異型がなかったため, そ れらのパラメータは算出できなかった. 表 3 に示すとお り, 異なる蛋白質, 種々の置換部位での变異型のデータで あるにもかかわらず, 各パラメータの值は非常に近い偪に なっていた。このことは, 安定化因子は蛋白質の種類に依 存せず, 普遍的なものとして定量化できる叮能性を示して いる. 次項に, これらのパラメータをほかの研究に適用で きる可能性について例を挙げる.

\section{6. 好熱菌蛋白質の安定性メカニズム解明への適用}

好熱菌のうちでも, 水の沸騰点近くの温度で生育する超 好熱菌由来蛋白質が最近精力的に研究されている. それら の変性温度は常温菌由来蛋白質に比べ非常に高く，一般に その菌の生育温度 $100^{\circ} \mathrm{C}$ り高い.この安定化のメカニズ ムとして, さまざまな因子が提案されているが, 超好熱菌 由来蛋白質に特徵的な安定化因子はいまだ見出されてい ない.はじめに述べたように, 蛋白質の安起性はわずかな エネルギーバランスで保たれているので, 安定化因子が少 し変化しただけでも安定性が見かけ上異常に高くなった ように見える，そのため，好熱菌由来蛋白質の安定化のメ カニズムを知るためには, 定性的に構造の特徽を常温菌由 来の相同蛋白質と見比べるだけでは不十分である。 そこ で，これまで述べてきたパラメータを利用して，好熱菌由 来蛋白質の安定性のメカニズムをどのように理解するか について, 2つの蛋白質を例に挙げて記す.101.111

超好熱菌Pyrococcus furiosus 由来トリプトファン合 成酵素 $\alpha$ サブユニット（Pf-Trp $\alpha)$ は常温菌 Salmonella typhimurium 由来の同 $\alpha$ サブユニット $($ St-Trp $\alpha)$ と比べて, 熱安定性が約 $35^{\circ} \mathrm{C}$ 高い $(\mathrm{pH} 9.5)$. 両蛋白質の熱測定の結 果から, Pf-Trp $\alpha$ の熱安定化はエンタルピーではなく, エン トロピーの寄与であることが示されている. St-Trp $\alpha$ の構造 は $\alpha_{2} \beta_{2}$ 複合体として既知であり,(2) $P f-\operatorname{Trp} \alpha$ はわれわれのグ ループによって最近解析された.1(1) そこで両者の構造を比 較し, HLのパラメータを用いて両蛋白質の安定化因子の 寄与を推定した (表 5). 疎水性相互作用の寄与 $\left(\Delta \Delta \mathrm{G}_{\mathrm{HP}}\right)$ はー $79.8 \mathrm{~kJ} / \mathrm{mol}$ で, St-Trpoのほうが, Pf-Trp $\alpha$ より安定化 への寄与が大きいことを示している.また，キャビティ $\left(\Delta \mathrm{G}_{\mathrm{cav}}\right)$ と静電的相互作用 $\left(\Delta \Delta \mathrm{G}_{\mathrm{ELE}}\right)$ の寄与はそれぞれ 11 $\mathrm{kJ} / \mathrm{mol}, 42.7 \mathrm{~kJ} / \mathrm{mol}$ であり, これらの因子はPf-Trpoの安 定性への寄与のほうが大きい.一般に, 柾水性相互作用は 蛋白質の安定化に重要な役割を果たしていると言われて いるが,ここに示すようにPf-Trp $\alpha$ の高い熱安定性は, 疎 水性相互作用の増加によるのではなく, キャビティ体積の
表 5 構造より見積もったそれぞれの安定化因子の寄与 $(\operatorname{Trp} \alpha)^{10)}$ (Estimate of the contribution of each stabilization factor from the structure of $\operatorname{Trp} \alpha$.)

\begin{tabular}{|c|c|c|c|}
\hline & $P f$-Trp $\alpha$ & St-Trp $\alpha$ & $\Delta(=P f-S t)$ \\
\hline \multicolumn{4}{|l|}{$\begin{array}{l}\text { Difference in ASA values } \\
\quad(\mathrm{D}-\mathrm{N})\end{array}$} \\
\hline $\mathrm{C} / \mathrm{S}$ atoms $\left(\AA^{2}\right)$ & 16449 & 16918 & -469 \\
\hline N/O atoms $\left(\AA^{2}\right)$ & 6953 & 7214 & -261 \\
\hline$\Delta \mathbf{G}_{\mathrm{HP}}(\mathbf{k J} / \mathbf{m o l})$ & 2837.3 & 2917.1 & -79.8 \\
\hline Cavity Vol. (probe 1.4 $\AA)\left(\AA^{3}\right)$ & 226.75 & 318.07 & -91.32 \\
\hline$\Delta \mathbf{G}_{\mathrm{CAv}}(\mathbf{k J} / \mathbf{m o l})$ & -27.2 & -38.2 & 11.0 \\
\hline Total number of residues & 248 & 268 & -20 \\
\hline$\Delta \mathbf{G}_{\text {conf }}$ at $25^{\circ} \mathrm{C}(\mathrm{kJ} / \mathrm{mol})$ & & & 291.8 \\
\hline$\Delta \mathbf{G}_{\text {conf }}$ at $60^{\circ} \mathrm{C}(\mathrm{kJ} / \mathrm{mol})$ & & & 326.2 \\
\hline \multicolumn{4}{|l|}{ Electrostatic energy } \\
\hline$\Delta \mathbf{G}_{\mathrm{ELE}}(\mathbf{k J} / \mathbf{m o l})$ & 80.4 & 37.7 & 42.7 \\
\hline
\end{tabular}

表 6 構造より見積もったそれぞれの安定化因子の寄与 (PRAI).11) (Estimate of the contribution of each stabilization factor from the structure of PPAI.)

\begin{tabular}{|c|c|c|c|}
\hline \multirow{3}{*}{$\begin{array}{l}\text { Difference in monomer ASA values } \\
(\mathrm{D}-\mathrm{N})\end{array}$} & \multicolumn{3}{|c|}{$T m$-PRAI $T t$-PRAI $\Delta(=T m-T t)$} \\
\hline & & & \\
\hline & & & \\
\hline $\mathrm{C} / \mathrm{S}$ atoms $\left(\AA^{2}\right)$ & 13097 & 13171 & -74 \\
\hline N/O atoms $\left(\AA^{2}\right)$ & 5247 & 5097 & 150 \\
\hline$\Delta \mathbf{G}_{\mathbf{H P}}(\mathbf{k J} / \mathbf{m o l})$ & 1881 & 1896 & -15 \\
\hline \multicolumn{4}{|c|}{ Difference in dimer interface area } \\
\hline $\mathrm{C} / \mathrm{S}$ atoms $\left(\AA^{2}\right)$ & 1765 & 1440 & 325 \\
\hline $\mathrm{N} / \mathrm{O}$ atoms $\left(\AA^{2}\right)$ & 1306 & 1074 & 232 \\
\hline$\Delta \mathbf{G}_{\mathbf{H P}}(\mathbf{k J} / \mathbf{m o l})$ & 238 & 194 & 44 \\
\hline \multicolumn{4}{|c|}{ Cavity Vol. (probe $1.4 \AA)\left(\AA^{3}\right)$} \\
\hline monomer & 15 & 80 & -65 \\
\hline$\Delta \mathbf{G}_{\mathrm{CAV}}(\mathbf{k J} / \mathbf{m o l})$ & -0.8 & -4.2 & 3.5 \\
\hline dimer & 76 & 312 & -236 \\
\hline$\Delta \mathbf{G}_{\mathbf{C A V}}(\mathbf{k} \mathbf{J} / \mathbf{m o l})($ dimer $)$ & 4.0 & -16.2 & 12.2 \\
\hline
\end{tabular}

減少, 静電的相互作用 (イオン結合) の増加, および残基工 ントロピー項の寄与に依存していることがこの解析によ ってわかった.10)

超好熱菌 Thermotoga maritimaのホスホリボシルアント ラニル酸イソメラーゼ (Tm-PRAI) と高度好熱菌 Thermus thermophilus HB8 由来の同蛋白質 (Tt-PRAI) は, いずれ も 2 量体構造で, その構造はサブユニット界面で疎水性の 突出部が互いに入り組んでいる. Tt-PRAI は酸性領域で単 量体に解離し変性するが, Tm-PRAI は, Tt-PRAIがすでに 変性している $\mathrm{pH} 2.3$ でも 2 量体を維持し intact な構造で あることが知られている.そこで, Tm-PRAIの 2 量体安定 化の原因を両者の構造から調べた. 表 6 にHLのパラメー 夕を用いて推定した, 再蛋白質の安定化因子の寄与を示 す. 疎水性相互作用の寄与により, 単量体の場合 $T t$-PRAI のほうが $15 \mathrm{~kJ} / \mathrm{mol}$ 安定化されているが, 2 量体のサブユ ニット接触界面では, Tm-PRAIのほうが $44 \mathrm{~kJ} / \mathrm{mol}$ 安定 
化されている.つまり Tm-PRAI の安定性への疎水性相互作 用の寄与は, 単量体では $T t$-PRAI よりも少ないが, 接触界 面でより大きく安定化されていることを示している. また, キャビテイ減少による尣篎化への帮与は, 単量体も 2 量体 もいずれも Tm-PRAIに有利になっている.さらに, 水素結 合およびイオン結合は両蛋白質で有意な差は見られなか ったので, 酸性中でTm-PRAIがより安定性が高いのは, ダ イマー間の疎水性相互.作用とキャビティの大きさの差に よることが両者の立体構造の解析からわかった.11)

\section{7. 創薬化学への適用}

病気の原因となる医薬の標的分子のほとんどは蛋白質 である. 例えばホルモンや神経伝達物質の受容体, 特異的 蛋白質分解酵素, 細菌の細胞代謝や細胞壁形成などにかか わる酵素はみな蛋白質である.このような標的蛋白質に薬 剤 (低分子化合物) がどのように結合して蛋向質の機能を 阻害するかを, 複合体 X 線結晶構造解析やコンピュー夕 モデリングより明らかにし，その構造情報を用いて医薬品 候補化合物を探索する手法は Structure-Based Drug Design (SBDD) と呼ばれ, 効㻭的・合理的に厌薬品を探索する手 法として注目されている.131

SBDD では, 複合体X線結晶構造解析により, 実駼的に 標的蛋白質と化合物の結合様式を明らかにするのが理想 であるが, 標的蛋白質の立体構造が得られない場合や，多 数の化合物について個々にどのように標的蛋白質に結合 しているかを知りたい場合, コンピュータモデリングを用 いて子予測することが多い，この手法では，まず化合物が標 的蛋白質の結合ポケット(例えば活性部位)に当てはまる かどうか, 化合物をフィッティング (ドッキング)させて 予測する，その予測結合様式を基に, 化合物と標的蛋白質 との結合の強さを推測し, 多数の中から強い化合物を選択 したり，さらに結合が強くなるように化合物をデザインし たりする.しかしこの標的蛋占質と化合物の結合の強さ を見積もること (スコアリング) は非常に難しい. 分子動 力学 $(\mathrm{MD})$ 計算などにより，1つ1つの化合物について詳 細にシミュレーションすることも叮能であるが, SBDDに おいては多数の化合物を扱う必要があり, 短時開で簡易的 に結合の強さを予測することが要求される.

現在知られているスコア関数は, エネルギー計算から得 られるものや, 経験的なものなど多数存在する. Wang ${ }^{14)}$ は, 利用可能な 11 種のスコア関数 (PLP, F-Score, LigScore, DrugScore, LUDI, X-Score, AutoDock, PMF, G-Score, ChemScore, D-Score) を比較した. その結果, なかでもXScoreや DrugScore で比較的良い結果が得られることがわ かった. 経験的スコア関数であるX-Score ${ }^{15)}$ を例に挙げる と,式 (8) で表されるように, 阻害剂の結合の強さ $\left(\Delta \mathrm{G}_{\text {bind }}\right)$ を, ファンデルワールス相互作用の寄与 $\left(\Delta \mathrm{G}_{\mathrm{vdw}}\right)$, 水素結 合の寄与. $\left(\Delta \mathrm{G}_{\mathrm{H} \text {-bond }}\right)$, ゆがみの寄与 $\left(\Delta \mathrm{G}_{\text {deformation }}\right)$, 疎水性 日本結晶学会誌 第 47 巻 第 4 号 (2005)
相互作用の寄与 $\left(\Delta \mathrm{G}_{\mathrm{hydrophobic}}\right)$ の和と仮定し, 200 種の蛋 白質実験データから経験的に導いたスコア関数となって いる。ここで $\Delta \mathrm{G}_{\text {bind }}$ は実験的に得られた解離平衡係数 $\left(p K_{d}\right)$ から算出した値を用いており，また $\Delta \mathrm{G}_{\text {hydrophobic }}$ は ASAが指標に用いられている.

$$
\begin{aligned}
\Delta \mathrm{G}_{\text {bind }}= & \Delta \mathrm{G}_{\mathrm{vdw}}+\Delta \mathrm{G}_{\mathrm{H} \text {-bond }}+\Delta \mathrm{G}_{\text {deformation }} \\
& +\Delta \mathrm{G}_{\text {hydrophobic }}+\Delta \mathrm{G}_{0}
\end{aligned}
$$

スコア関数の中には無償で利用可能なものもあるが,一 般的には有料である。しかし，例に挙げたような経験的ス コア関数の決定法は, 上述のように $\mathrm{HL}$ 変異型を用いて安 定化因子の寄与を定量化した手法とよく似ている。 そこ で, 蛋白質の安定化因子を定量的に見積もることができる 上述のパラメータが利用できないかと考えた。

蛋的質の安定性がさまざまな因子によって変化するの と同様に, 化合物と蛋向質の結命の強さもさまざまな因子 に影響され，代表的なものとして疎水性相互作用，水素結 合, 化合物のエントロピー変化が挙げられる. 疎水性相 互作用は，式 (2) と闬様に $\Delta \mathrm{ASA}$ (結合による溶媒露出面 積変化）を用いて記述できるが, 化合物にはハロゲン原子 が含まれる場合があるため, 疎水性相互作用の寄与は, 式 (9)のようにハロゲンの表面積も考慮する必要がある.

$$
\begin{aligned}
\Delta \Delta \mathrm{G}_{\mathrm{HP}}= & \alpha^{\prime} \Delta \Delta \mathrm{ASA}_{\text {non-polar }}+\beta^{\prime} \Delta \Delta \mathrm{ASA}_{\text {polar }} \\
& +\gamma^{\prime} \Delta \Delta \mathrm{ASA}_{\text {hallogen }}
\end{aligned}
$$

また，蛋白質の安定性 $\left(\Delta \Delta \mathrm{G}_{\mathrm{exp}}\right)$ に対応するものとしては, 実験的に測定された $p K_{d}$ などの值を用いるのが望ましい が, 使用できるデータが限られるため, $\mathrm{IC}_{50}$ 値 (結合親和 性：蛋白質機能の 50 \%が阻害される化合物濃度）を用い ることにした，具体的には，複数の標的蛋白質に多数の 化合物をコンピュータ上でドッキングさせ, 予測結合様 式から得られる ASA なとの值と，実験的に得られた $\mathrm{IC}_{50}$ の值を用い, 同様の手法で各因子のパラメー夕を最小自乗 法で決定した，その結果，例えば $\alpha^{\prime}, \beta^{\prime}, \gamma^{\prime}$ はそれぞれ 0.041 , - 0.004, 0.025 となり, 得られたパラメー夕を用いて算出 して結合が強いと予測される化合物のほうが，より強い阻 害剤であるという傾问が見られている，興味深いことに， それらのパラメータは, HL変異型から得られた值と非常 によく似ていたこのことは安定化因子の寄与を定量的に 見積もることができるようになれば，そのまま蛋白質と化 合物の強さを見積もるのにも利用できる可能性を示唆し ている.

標的蛋白質の機能を阻害する化合物の探索の例を上に 示したが, 薬として世に出ているものは化合物だけではな い. 蛋白質そのものや，抗体，ペプチドなども蛋白質医薬 品として使用されている. しかし化合物 (固形の薬剂) と 異なり液体の楽剤である場合が多く, 安定性を確保するの が難しい，一般的に冷蔵や冷凍保存しなけ札ばならない場 
合が多いが, 常温でも安定に保存できる蛋白質医薬品が求 められている. 現在でもアミノ酸置換によって常温で保存 できる蛋白質医薬品は存在するが, 蛋白質の安定性を定 量的に見積もることができるようになれば, 蛋白質の機 能を維持したまま安定化させるデザインが容易に可能に なり，蛋白質医薬品の開発にも貢献できると考えられる.

\section{8. まとめ}

述べてきたように, 蛋白質立体構造を用い, その構造上 の特性と関連させることにより, 安定化因子の定量的評 価が可能であることを示してきた。これらの結果は, 好熱 菌由来蛋白質の安定性メカニズムの解明や,ドラッグデ ザイン, 蛋白質医薬品の開発など役立てられる. パラメー 夕を用いて簡易的に算出したアミノ酸側鎖の安定性への 寄与 $\left(\Delta \Delta \mathrm{G}_{\mathrm{aa}}\right)$ を表 7 に示すが,16)これらの值を用いれば, なお一層利用しやすいと考えられる。しかし, さらに詳細 にさまざまの安定化因子の寄与を定量化するには, 系統 的で網羅的な变異型の立体構造/安定性のデー夕が非常 に重要である. 現状ではまだデータが豊富であるとは言 えず, 今回使用した変異型デー夕も約 100 種に過ぎない が，オーダーが一桁上がればデータベースも充実したも のになり，同様の手法を用いてさらに精度高く評価がで きるようになると考えられる. 先に述べたと扔り,アミノ 酸配列中に含まれている立体構造・機能に関する情報を 解読するためにも，その立体構造を安定に維持させてい る因子について定量的に理解することが重要で, 今後さ らなる研究が必要である.

表7 各アミノ酸が安定性に及ぼす影響.16)(Side-chain contribution to protein stability.)

\begin{tabular}{cc}
\hline アミノ酸 & $\Delta \Delta \mathrm{G}_{\mathrm{aa}} *(\mathrm{~kJ} / \mathrm{mol})$ \\
\hline Ala & 9.8 \\
Arg & 7.3 \\
Asn & 3.6 \\
Asp & 4.9 \\
Cys & 3.0 \\
Gln & 2.4 \\
Glu & 4.4 \\
Gly & 0.0 \\
His & 11.9 \\
Ile & 17.2 \\
Leu & 17.0 \\
Lys & 10.5 \\
Met & 11.9 \\
Phe & 23.0 \\
Pro & 15.0 \\
Ser & 2.6 \\
Thr & 6.9 \\
Trp & 24.2 \\
Tyr & 17.2 \\
Val & 15.3 \\
\hline$\Delta \Delta \mathrm{G}_{\mathrm{aa}}=\Delta \Delta \mathrm{G}_{\mathrm{HP}}+\Delta \Delta \mathrm{G}_{\text {conf }}$ & \\
\hline
\end{tabular}

\section{文 献}

1) C. N. Pace: J. Mol. Biol. 226, 29 (1992).

2) P. L. Privalov and S. J. Gill: Adv. Protein Chem. 39, 191 (1988).

3) K. Takano, K. Ogasahara, H. Kaneda, Y. Yamagata, S. Fujii, E. Kanaya, M. Kikuchi, M. Oobatake and K. Yutani: J. Mol. Biol. 254, 62 (1995).

4) K. Takano, J. Funahashi, Y. Yamagata, S. Fujii and K. Yutani: J. Mol. Biol. 274, 132 (1997).

5) K. Takano, Y. Yamagata and K. Yutani: J. Mol. Biol. 280, 749 (1998).

6) J. Funahashi, K. Takano and K. Yutani: Protein Eng. 14, 127 (2001).

7) K. Takano, K. Tsuchimori, Y. Yamagata and K. Yutani: Biochemistry 39, 12375 (2000).

8) J. Funahashi, K. Takano, Y. Yamagata and K. Yutani: J. Biol. Chem. 277, 21792 (2002).

9) M. Nakasako: J. Mol. Biol. 289, 547 (1999).

10) Y. Yamagata, K. Ogasahara, Y. Hioki, S. J. Lee, A. Nakagawa, H. Nakamura, M. Ishida, S. Kuramitsu and K. Yutani: J. Biol. Chem. 276, 11062 (2001).

11) J. Taka, K. Ogasahara, J. Jeyakanthan, N. Kunishima, C. Kuroishi, M. Sugahara, S. Yokoyama and K. Yutani: J. Biochem. 137, 569 (2005).

12) C. C. Hyde, S. A. Ahmed, E. A. Paduardo, E. W. Miles and D. R. Davis: J. Biol. Chem. 263, 17857 (1988).

13) D. B. Boyd: Mod. Drug Disc. 1, 41 (1998).

14) R. Wang, Y. Lu and S. Wang: J. Med. Chem. 46, 2287 (2003).

15) R. Wang, L. Lai and S. Wang: J. Computer-Aided Mol. Des. 16, 11 (2002).

16) K. Takano and K. Yutani: Protein Eng. 14, 525 (2001).

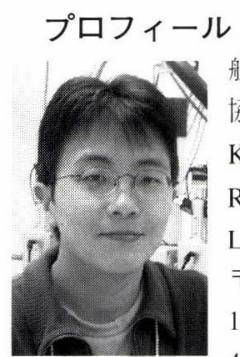
舩橋 順 Jun FUNAHASHI 協和発酵工業株) 医薬研究センター 創薬化学研究所 KYOWA HAKKO KOGYO Co., LTD. Pharmaceutical Research Center, Medicinal Chemistry Research Laboratories † 411-8731 静岡県駿東郡長泉町下土狩 1188 1188 Shimotogari, Nagaizumi-cho, Sunto-gun, Shizuoka 411-8731, Japan TEL. 055-989-2016, FAX. 055-986-7430 e-mail: jun.funahashi@kyowa.co.jp 最終学歴: 大阪大学大学院理学研究科高分子科学 専攻博士課程修了 専門分野：生物物理学・分子モデリング

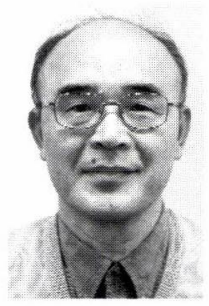

油谷克英 Katsuhide YUTANI 理化学研究所 播磨研究所

RIKEN Harima Institute T 679-5148 兵庫県佐用郡三日月町光都 1-1-1 1-1-1 Kouto, Mikazuki-cho, Sayo-gun, Hyogo 6795148, Japan TEL. 079-58-2937, FAX. 079-58-2917 e-mail: yutani@spring8.or.jp 最終学歴: 大阪大学理学部生物学科 専門分野: 蛋白質物理化学 